\title{
Research on the Interaction between Innovation and Port-City Economic System: A Case from China
}

\author{
Zhen Chen ${ }^{1,2}$ \\ ${ }^{1}$ Business School, Lingnan Normal University, Zhanjiang 524048, China \\ ${ }^{2}$ South China Sea Silk Road Collaborative Innovation Centre, Lingnan Normal University, Zhanjiang 524048, China
}

Correspondence should be addressed to Zhen Chen; 1892936@qq.com

Received 6 April 2015; Revised 5 October 2015; Accepted 7 October 2015

Academic Editor: Allan C. Peterson

Copyright (C) 2015 Zhen Chen. This is an open access article distributed under the Creative Commons Attribution License, which permits unrestricted use, distribution, and reproduction in any medium, provided the original work is properly cited.

\begin{abstract}
Port city is the node in global commodity flows. It is open to the outside world and often the primary test field of new economic development model. To reduce the negative impact of the global economic crisis since 2008, various developing patterns have been tested in the port city. And the most effective way should rely on the city's operation mechanism. Here a System Dynamics model is established to analyze the interaction process of the elements in the port-city system. Then choose Shenzhen city as the empirical case. By changing the proportion of R\&D and fixed-asset investment, the impact of different economic measures on the system could be confirmed. The result shows that, in order to stabilize the port city's economic growth, it should change the traditional development pattern to the innovation driven one. The former focuses on facilities investment and capacity expansion. The latter aims at port efficiency promoting and port business value increases.
\end{abstract}

\section{Introduction}

As the connection point of water and land transport, port plays an important role in the modern transportation networks. With the globalization of economics, international industry transfer is increasingly frequent. More and more different types of industries have been gathered around the port, so that the port economics has become an important force to promote regional economic development. Port and its region, especially the city, are an interdependent unity. From a perspective of system science, the port and city economics should be analyzed in the same frame. The study of the interaction between them would help formulating proper measures to optimize the economic development.

In this decade, there are a lot of academic ideas from the perspective of port and city. Xu pointed out that the port and the city have a complementary symbiotic relationship. The core of port-city linkage is the development of the port industry [1]. When a variety of port industries grew up, the supporting logistics services became diversified. And in recent years the logistics integration and network happened in port and maritime industry. Notteboom and Rodrigue redefined the functional role of ports in value chains, by introducing new patterns of freight distribution and new approaches to port hierarchy [2]. For the future development of port, Sun and Liu thought it was the fourth generation port being shaped. It should be the core of the whole city's industrial layout and function positioning [3]. For the linkage between port functions and the city's economy, Ducruet and Lee have done the comparison of the urban population and container throughput of 653 places between 1970 and 2005, based on a matrix of port-city centrality and intermediacy. Their conclusion is that the port-city evolution is largely influenced by regional factors and local strategies. It developed gradually but not linearly or chaotically [4]. Grossmann discussed that the global technological, organizational, and economic developments had affected port-dependent jobs. The city should make change according to the port's developing trend. Otherwise, the lock-in port city would lose market shares to competitors [5]. Hou established a port sustainable economic development model. He found that the expansion of the port function enhanced the development of port economics. The shipping service industry based on the port development would bring jobs to city population [6]. 
Jacobs et al. figured that the port cities are the nodes in global commodity flows. And they could provide advanced services related to shipping and port activities. It would help them get promoted to higher world city hierarchy [7]. Pan and Cao pointed out that the port value chain, the logistics resources integration, the port foreland, and other new areas would be study trends and frontiers of port geography [8].

The above research mainly suggested that the port city should make use of its advantage of node in global commodity. When the logistics integration and advanced maritime related services got improved, the port function would be expanded. The port city would be promoted to higher hierarchy.

To enhance the port function and upgrade the port industry, fixed-assets investment, especially infrastructure investment, is the first and important step. Improving port facilities could increase the port throughput capacity and expand the scale of port industries. It is an instant way to develop the economics. Therefore, after 2008, to reduce the negative effect of the global financial crisis, many port cities have increased their investment in wharf and coastal factories, especially the cities in China. That could expand the production capacity and maintain the economic growth.

This growth pattern has the outstanding characteristics of the two aspects: one is the rapid growth speed and the other is the structural contradiction. This extensive growth mode is unbalanced, uncoordinated, and unsustainable. The expansion of production capacity will reach a limitation. As a result of overinvestment, after a period of rapid growth, China's economic growth acted not so well. Now the Chinese decision makers are trying to optimize their economics structure. That means reducing the overinvestment and changing the developing pattern [9].

Chu investigated the long-run relationship between logistics investment and economic growth based on China's samples. He found that the logistics investment contributed more to interior provinces than coastal ones [10]. So the coastal cities should look for other growth measures than the investment. The globalization has brought the port city a cluster of various kinds of industry. That would bring the city Jacobs' externality effects. Neffke et al. studied the cases in Sweden and found that Jacobs' externality benefits young enterprises more [11]. It proves that innovation is an effective way for the port-city development. The developing pattern of port city could be shifted from investment driven to innovation driven.

How can we effectively stimulate the regional innovation? In early 1999, Boschma has proposed the concept "cluster of innovative industries." It means that interdependencies and complementarities would occur between a set of industries in a particular period, because of their dynamic technoeconomic linkages [12]. After a few years, he put forward the idea that the geographical proximity was good for innovation, through strengthening the other dimensions of proximity. But it would also have negative impacts on interactive learning due to the problem of lockin. An effective mechanism should be set to ensure the openness and flexibility of interactive learning [13]. About the relationship between industrial innovation and economic development, Frenken and Boschma provided a framework based on the microfoundation of economy geography, to determine the interaction between industrial dynamics and urban growth. Under the constraint condition of increasing wages, the spatial concentration of industries and specialization of cities would gain from economies of scope and Jacobs' externalities [14]. In 2009, Boschma presented that related variety could induce knowledge transfer between complementary sectors at the regional level. That would help industrial renewal and economic branching in regions. The spinoff activity, labor mobility, and network formation should be encouraged to achieve it [15]. Neffke et al. have found that industries, which were technologically related to preexisting industries in a region, were easier to enter the region. And the related industries have high degree of technological coherence [16]. When it comes to the innovation of port city, it should focus more on the industries related to the port, such as port logistics and import and export trade.

\section{Research Ideas}

2.1. Related Concepts. To measure the effective innovation input, the key is operating $\mathrm{R} \& \mathrm{D}$ activities under the correct guidance of the decision-making departments. $\mathrm{R} \& \mathrm{D}$ means Research and Development. It refers to creating a system for new applications, to increase the total amount of knowledge and use the knowledge of creative activities in the field of science and technology. As for port business, it needs to improve the port operation efficiency by technical R\&D. That could promote the industry integration as well as increasing the unit-added value of cargo [17]. To "dig" more for benefit in the same economic volume, it is the important approach for the port city's stable economic growth [18].

For better integrating R\&D into the port industry, the port-city interactive mechanism should be determined. This mechanism is the sum of nonlinear relationship among the elements' interactions, mutual feedback in the port and city systems. By changing the proportion of R\&D and fixed-asset investment, the elements' variation trends in the system could be determined. The merits of the two different modes, investment driven and the innovation driven, could be compared and make the optimal decision of industrial structure [19].

2.2. Model Selection. This paper selects System Dynamics to construct the port-city interaction model. System Dynamics is a simulation technology that studies complex systems based on feedback control theory. It is to establish the synthetical model by using the system structure and the relation of feedback loops. Then through the simulation experiment, it could deal with the high order, nonlinear, multiple feedback issues of complex time-varying system. The research object of this paper, the interactive development of port and city, is a typical complex social system. System Dynamics is fit for the analysis of this system. The reasons are as follows:

(1) System Dynamics' diagram of cause-effect and flow chain can directly reflect the relationship and causality of different economic measures in port-city system. 
(2) System Dynamics could do the calculation by analyzing the causal relationships among each element in a fixed structure. So it does not need too many observations. That could avoid the simulation failure caused by insufficient data.

(3) System Dynamics is suitable for the solution of longterm and cyclical problems. The interaction between $\mathrm{R} \& \mathrm{D}$ and port-city economics has this characteristic [20].

\section{Modeling}

The modeling approach of port-city system is divided into two parts. The first is the cause-effect relationships diagram. And the second is the flow diagram. They both are the main steps of System Dynamics model construction.

3.1. The Cause-Effect Relationship Analysis of Port-City Interaction. The basic structure of System Dynamics model is feedback loop. The loop could reflect elements mutual connection and influence in the system. The cause-effect diagram consisting of feedback loops could express various qualitative relationships among the elements within the system clearly. Therefore, the key to establish the model is to determine the feedback loops. And the main feedback loops are as follows. In the loops, the arrows denote the cause-and-effect relationships and the plus and minus signs denote the positive and negative effects, respectively.

\subsubsection{The Main Feedback Loop Reflects the Interaction among Economic Growth, Port Requirement, and Logistics Industry Development}

(1) Total economic volume $\stackrel{+}{\rightarrow}$ total import and export volume $\stackrel{+}{\rightarrow}$ demand of port throughput $\stackrel{+}{\rightarrow}$ port throughput $\stackrel{+}{\rightarrow}$ logistics industry production.

The loop is positive. The port city's economic growth would increase the total volume of import and export trade and enhance the ocean transport demand and port throughput. Port throughput refers to the total amount of cargo loading and unloading in port in one year. This index could reflect prosperity of the port business. The further development of the port business requires more related logistics services from the port city, including cargo handling, storage and transfer, shipping freight, and the third party logistics.

\subsubsection{The Main Feedback Loop Reflects the Promotion of Port Capacity from the Fixed-Asset Investment}

(1) Total economic volume $\stackrel{+}{\rightarrow}$ fixed-asset investment $\stackrel{+}{\rightarrow}$ logistics industry production.

(2) Total economic volume $\stackrel{+}{\rightarrow}$ fixed-asset investment $\stackrel{+}{\rightarrow}$ port throughput capacity $\stackrel{-}{\rightarrow}$ port throughput shortage.
The first loop is positive. The port city's economic growth would speed up the fixed-asset investment, including the infrastructure construction. Improving of the port, road, and other public facilities would have a positive impact on the development of logistics industry.

The second loop is negative. The improvement of the infrastructure would enhance the port throughput capacity. Port throughput capacity means the maximum amount of cargo loading and unloading in port, in certain technical equipment and labor organization conditions. The increase of port throughput capacity would reduce the port throughput shortage.

\subsubsection{The Main Feedback Loop Reflects the Promotion of Port Capacity and Port-City Economics from R\&D}

(1) Total economic volume $\stackrel{+}{\rightarrow} \mathrm{R} \& \mathrm{D} \stackrel{+}{\rightarrow}$ high-tech industry production $\stackrel{+}{\rightarrow}$ port throughput demand $\stackrel{+}{\rightarrow}$ port throughput $\stackrel{+}{\rightarrow}$ logistics industry production.

(2) Total economic volume $\stackrel{+}{\rightarrow} \mathrm{R} \& \mathrm{D} \stackrel{+}{\rightarrow}$ port operation efficiency $\stackrel{+}{\rightarrow}$ port throughput $\stackrel{+}{\rightarrow}$ logistics industry production.

The two loops above are positive. The port city's economic growth would stimulate the government and enterprises' R\&D input to develop new high technology. On the one hand, the new high-tech product trade would enhance the port throughput demand. On the other hand, the new high-tech application would promote the port operation efficiency. The actual port throughput could get supplied when the efficiency improved. These both driving forces would increase the port throughput and help develop the logistics industry.

\subsubsection{The Main Feedback Loop Reflects the Interaction between the Port City's Economics and Population}

(1) Total economic volume $\stackrel{+}{\rightarrow}$ population attraction $\stackrel{+}{\rightarrow}$ labor force.

The loop is positive. The port city's economic growth would enhance the city's population attraction. The number of labor forces, including researchers, would increase. Then the growth of labor force could stimulate all industries' development in the city.

Thus, the cause-effect relationship diagram is established (see Figure 1) by incorporating the various loops associated with the system.

3.2. The Construction of Port-City System Flow Program. According to the cause-effect diagram above and the analysis of the system's feedback mechanisms, the flow diagram of port-city interaction is established as in Figure 2. The variable port-city GDP represents the city's economic volume. 


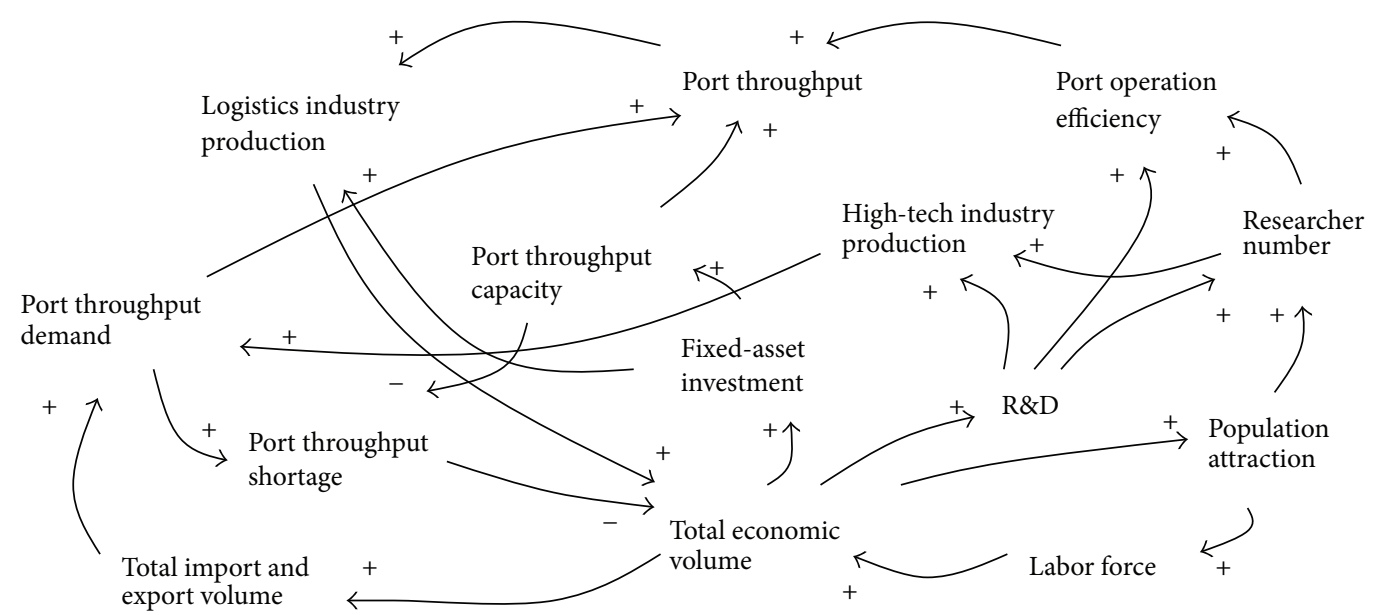

FIGURE 1: The cause-effect diagram of port-city interaction system.

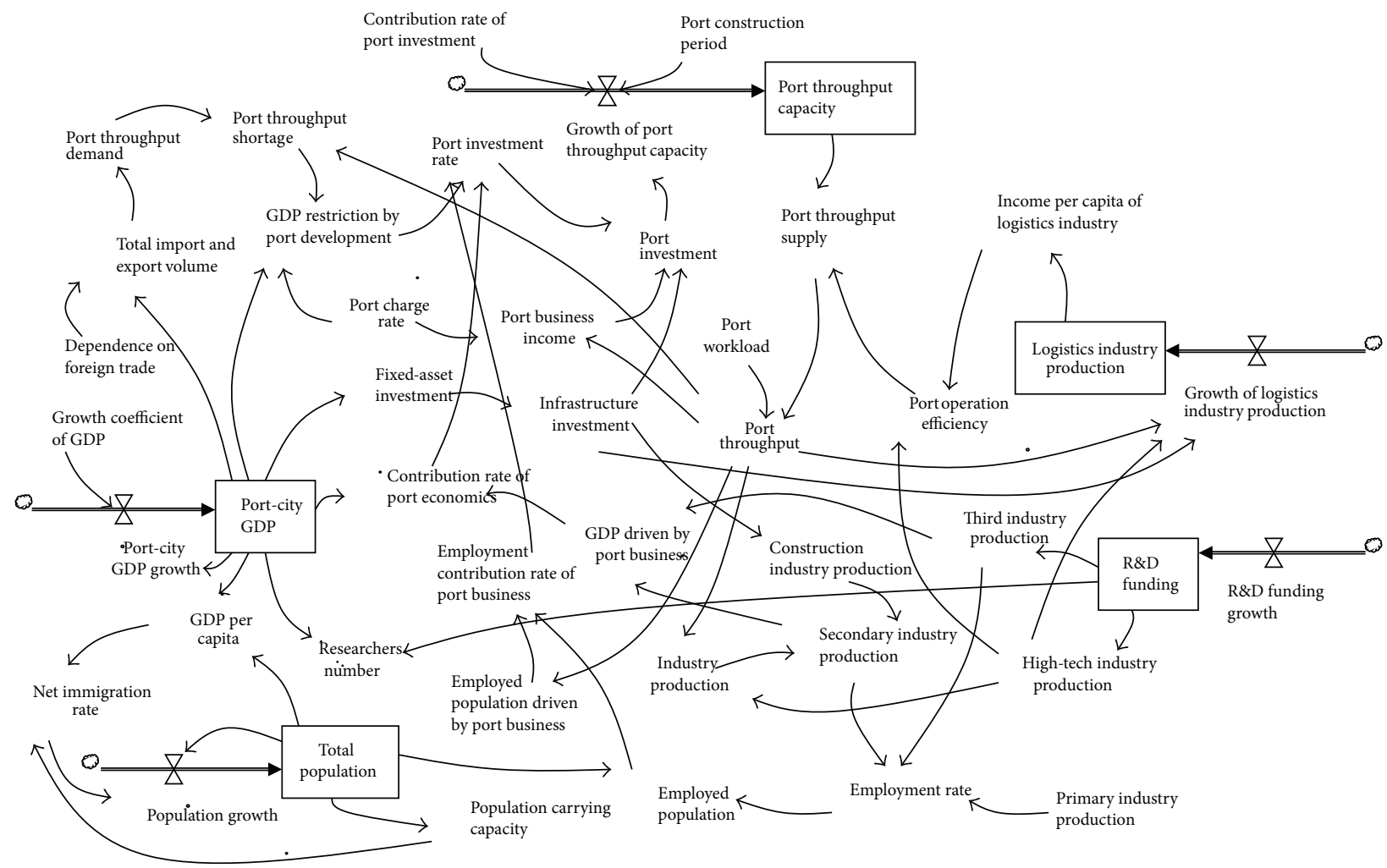

FIGURE 2: The flow diagram of port-city interaction system.

\subsubsection{The Main Equations Reflecting the Interaction} among Economic Growth, Port Requirement, and Logistics Industry Development

(1) Port-city GDP = INTEG (port-city GDP growth, initial value).

(2) Total import and export volume $=$ port-city GDP $*$ dependence on foreign trade.
(3) Port throughput demand = total import and export volume $*$ transformation coefficient of port throughput + constant.

(4) Port throughput supply $=$ port throughput capacity * port operation efficiency.

(5) Port throughput $=$ port throughput supply $*$ port work load. 
(6) Port throughput shortage = IF THEN ELSE (port throughput demand $>$ port throughput, port throughput demand - port throughput, 0).

(7) Contribution rate of port economics = GDP driven by port business/port-city GDP.

(8) GDP restriction by port development = port throughput shortage $*$ port charge rate/port-city GDP.

(9) Logistics industry production = INTEG (growth of logistics industry production, initial value).

(10) Growth of logistics industry production = port throughput $*$ driven coefficient by port throughput + infrastructure investment $*$ driven coefficient by infrastructure + high-tech industry production $*$ logistics driven coefficient by high technology + constant.

\subsubsection{The Main Equations Reflecting the Promotion of Port Capacity from the Fixed-Asset Investment}

(1) Fixed-asset investment = port-city GDP $*$ investment coefficient of fixed-asset + constant.

(2) Port investment $=($ infrastructure investment $*$ port investment rate + port business income) $*$ investment ratio coefficient.

(3) Port investment rate $=$ contribution rate of port economics $*$ driven coefficient by economics + employment contribution rate of port business $*$ driven coefficient by employment + GDP restriction by port development $*$ restriction coefficient by port throughput shortage.

(4) Growth of port throughput capacity = DELAY1 (port investment $*$ contribution rate of port investment, port construction period).

(5) Port throughput capacity = INTEG (growth of port throughput capacity, initial value).

\subsubsection{The Main Equations Reflecting the Promotion of Port Capacity and Port-City Economics from R\&D}

(1) Port operation efficiency $=$ high-tech industry production $*$ port driven coefficient by high technology + income per capita of logistics industry $*$ driven coefficient by personal income + constant.

(2) $\mathrm{R} \& \mathrm{D}$ funding $=$ INTEG $(\mathrm{R} \& \mathrm{D}$ funding growth, initial value).

(3) R\&D funding growth = port-city GDP $*$ input coefficient of $\mathrm{R} \& \mathrm{D}+$ constant.

(4) High-tech industry production $=\mathrm{R} \& \mathrm{D}$ funding $*$ driven coefficient by funding + researchers number * driven coefficient by talents + constant.
3.2.4. The Main Equations Reflecting the Interaction between the Port City's Economics and Population

(1) Total population = INTEG (population growth, initial value).

(2) Employed population $=$ total population $*$ employment rate.

(3) Employment rate $=$ primary industry production $*$ employment coefficient of primary industry + secondary industry production $*$ employment coefficient of secondary industry + third industry production * employment coefficient of third industry + constant.

(4) Secondary industry production = industry production + construction industry production.

(5) Third industry production = logistics industry production $*$ driven coefficient by logistics $+\mathrm{R} \& \mathrm{D}$ funding $*$ driven coefficient by innovation + constant.

(6) Researchers number $=$ port-city GDP $*$ talent attraction coefficient by GDP $+\mathrm{R} \& \mathrm{D}$ funding $*$ talent incentive coefficient by $\mathrm{R} \& \mathrm{D}+$ constant.

(7) Employment contribution rate of port business = employed population driven by port business/employed population.

\section{A Case Study}

4.1. Introduction of Study Subject. This paper selects Shenzhen city as the research object. Shenzhen city locates on the east coast of Pearl River Estuary. It is one of the four first-tier cities in China. In the aspect of port capacity, Shenzhen port is an important transportation hub port in the Pearl River Delta. Since 2004, the container throughput of Shenzhen port has been located in the top four in the world. In the aspect of science and technology, Shenzhen's invention patent quantity for every million people is ranked first in Chinese cities. Therefore, logistics industry based on port business and hightech industry based on scientific R\&D are the symbols of Shenzhen city.

4.2. The Source of Research Data and the Test of Model Validation. The main part of the data is from the "Shenzhen Statistical Yearbook." The other is from the actual investigation and research of Shenzhen city. The consistency check of the model structure and dimension is conducted by VENSIM software. Then a historic inspection is conducted based on the years of 2008-2012 data. The reason for the data period is that after 2008 many cities in China increase their investment in fixed-assets. But different from other cities, Shenzhen still kept a part of resource for $\mathrm{R} \& \mathrm{D}$ activities. The inspection result is as follows.

The main variables' simulation and actual values are shown in Table 1 . The fitting error between model result and actual data is less than $10 \%$. It proves that the model is suitable for behavior replication and simulating the actual operation of the Shenzhen port-city economic system. Then test the 
TABLE 1: The comparison between the simulation and actual value of the model's main variables.

\begin{tabular}{|c|c|c|c|c|c|}
\hline Variable & 2008 & 2009 & 2010 & 2011 & 2012 \\
\hline \multicolumn{6}{|c|}{ Port-city GDP ( $10^{9}$ Yuan $)$} \\
\hline Simulation & 778.7 & 884.9 & 1005.7 & 1143.0 & 1299.1 \\
\hline Actual & 778.7 & 820.1 & 958.2 & 1159.6 & 1295.0 \\
\hline Deviation rate & $0.00 \%$ & $7.90 \%$ & $4.96 \%$ & $-1.43 \%$ & $0.32 \%$ \\
\hline \multicolumn{6}{|c|}{ Port throughput ( $10^{8}$ Ton) } \\
\hline Simulation & 1.963 & 1.909 & 2.021 & 2.135 & 2.252 \\
\hline Actual & 2.113 & 1.936 & 2.215 & 2.238 & 2.281 \\
\hline Deviation rate & $-7.10 \%$ & $-1.39 \%$ & $-8.76 \%$ & $-4.60 \%$ & $-1.27 \%$ \\
\hline \multicolumn{6}{|c|}{ Fixed-asset investment ( $10^{9}$ Yuan) } \\
\hline Simulation & 156.6 & 172.9 & 187.8 & 204.7 & 223.9 \\
\hline Actual & 146.8 & 170.9 & 194.5 & 206.1 & 219.4 \\
\hline Deviation rate & $6.68 \%$ & $1.17 \%$ & $-3.44 \%$ & $-0.68 \%$ & $2.05 \%$ \\
\hline \multicolumn{6}{|c|}{ R\&D funding ( $10^{9}$ Yuan $)$} \\
\hline Simulation & 24.4 & 31.3 & 38.2 & 45.2 & 52.3 \\
\hline Actual & 24.4 & 30.9 & 39.5 & 46.5 & 53.0 \\
\hline Deviation rate & $0.00 \%$ & $1.29 \%$ & $-3.29 \%$ & $-2.80 \%$ & $-1.32 \%$ \\
\hline \multicolumn{6}{|c|}{ Logistics industry production $\left(10^{9}\right.$ Yuan $)$} \\
\hline Simulation & 29.8 & 31.7 & 35.4 & 41.0 & 48.4 \\
\hline Actual & 29.8 & 30.9 & 37.9 & 43.7 & 47.1 \\
\hline Deviation rate & $0.00 \%$ & $2.59 \%$ & $-6.60 \%$ & $-6.18 \%$ & $2.76 \%$ \\
\hline \multicolumn{6}{|c|}{ Total population $\left(10^{4}\right.$ people $)$} \\
\hline Simulation & 954 & 996 & 1033 & 1063 & 1084 \\
\hline Actual & 954 & 995 & 1037 & 1046 & 1054 \\
\hline Deviation rate & $0.00 \%$ & $0.10 \%$ & $-0.39 \%$ & $1.63 \%$ & $2.85 \%$ \\
\hline \multicolumn{6}{|c|}{ Researchers number $\left(10^{4}\right.$ people $)$} \\
\hline Simulation & 15.39 & 17.33 & 21.09 & 22.34 & 24.5 \\
\hline Actual & 16.24 & 16.19 & 22.6 & 21.89 & 25.08 \\
\hline Deviation rate & $-5.23 \%$ & $7.04 \%$ & $-6.68 \%$ & $2.06 \%$ & $-2.31 \%$ \\
\hline \multicolumn{6}{|c|}{ Secondary industry production ( $10^{9}$ Yuan) } \\
\hline Simulation & 366.5 & 407.8 & 469.5 & 521.7 & 574.6 \\
\hline Actual & 386.0 & 382.7 & 452.3 & 534.3 & 573.7 \\
\hline Deviation rate & $-5.05 \%$ & $6.56 \%$ & $3.80 \%$ & $-2.36 \%$ & $0.16 \%$ \\
\hline \multicolumn{6}{|c|}{ Third industry production ( $10^{9}$ Yuan $)$} \\
\hline Simulation & 380.7 & 436.9 & 509.4 & 598.4 & 704.2 \\
\hline Actual & 391.8 & 436.8 & 505.2 & 615.6 & 720.6 \\
\hline Deviation rate & $-2.83 \%$ & $0.02 \%$ & $0.83 \%$ & $-2.79 \%$ & $-2.28 \%$ \\
\hline
\end{tabular}

sensitivity and extreme conditions of model to confirm the model's certain sensitivity and stability.

\subsection{Simulation Experiment}

4.3.1. Scheme Design. The simulation is the key step in the application of System Dynamics model. By modifying the related parameters, the different economic measures could be simulated to create various circumstances. The potential problems existing in the system would be identified. The simulation focuses on two aspects. One is the industrial coordination between port and city. The other is the structure optimization of city's industry. It could improve the system's antirisk ability and achieve a friendly response of portcity social effect. That would provide a decision support of economic plans.

The historical data of the model is based on the years 2008-2012. And the prediction interval is set as 2013-2016. The time step is one year. Then choose five important coefficients as control factors. Their meanings are as follows:

(1) Investment coefficient of fixed-asset: it could reflect the intensity of fixed-asset investment.

(2) Input coefficient of R\&D: it could reflect the intensity of R\&D funding input. 
TABLE 2: The simulation scheme list.

\begin{tabular}{lcccccc}
\hline Number & Scheme description & $\begin{array}{c}\text { Investment } \\
\text { coefficient of } \\
\text { fixed-asset }\end{array}$ & $\begin{array}{c}\text { Input } \\
\text { coefficient of } \\
\text { R\&D }\end{array}$ & $\begin{array}{c}\text { Talent incentive } \\
\text { coefficient by } \\
\text { R\&D }\end{array}$ & $\begin{array}{c}\text { Port driven } \\
\text { coefficient by } \\
\text { high technology }\end{array}$ & $\begin{array}{c}\text { Logistics driven } \\
\text { coefficient by high } \\
\text { technology }\end{array}$ \\
\hline 1 & Control factors do not change & 0.1230 & 0.0005 & 0.0437 & 0.000005 & 0.0035 \\
2 & Increase fixed-asset investment & 0.1476 & 0.0005 & 0.0437 & 0.000005 & 0.0035 \\
3 & Increase R\&D funding input & 0.1230 & 0.0006 & 0.0437 & 0.000005 & 0.0035 \\
4 & Increase talent incentive by R\&D & 0.1230 & 0.0005 & 0.0524 & 0.000005 & 0.0035 \\
5 & $\begin{array}{c}\text { Increase R\&D which focus on port } \\
\text { efficiency improvement }\end{array}$ & 0.1230 & 0.0005 & 0.0437 & 0.000006 & 0.0035 \\
6 & $\begin{array}{c}\text { Increase R\&D which focus on logistics } \\
\text { added value improvement }\end{array}$ & 0.1230 & 0.0005 & 0.0437 & 0.000005 & 0.0042 \\
\hline
\end{tabular}

TABLE 3: The comparison of different simulation results.

\begin{tabular}{|c|c|c|c|c|c|c|}
\hline Index & Scheme 1 & Scheme 2 & Scheme 3 & Scheme 4 & Scheme 5 & Scheme 6 \\
\hline \multicolumn{7}{|c|}{ Port throughput ( $10^{8}$ Ton $)$} \\
\hline 2013 & 2.373 & 2.371 & 2.374 & 2.378 & 2.400 & 2.375 \\
\hline 2014 & 2.496 & 2.493 & 2.498 & 2.502 & 2.528 & 2.499 \\
\hline 2015 & 2.622 & 2.619 & 2.625 & 2.630 & 2.659 & 2.627 \\
\hline 2016 & 2.751 & 2.746 & 2.755 & 2.760 & 2.793 & 2.757 \\
\hline \multicolumn{7}{|c|}{ Logistics industry production ( $10^{9}$ Yuan) } \\
\hline 2013 & 57.7 & 57.1 & 57.7 & 58.0 & 58.9 & 59.9 \\
\hline 2014 & 68.9 & 68.1 & 69.0 & 69.4 & 70.5 & 71.8 \\
\hline 2015 & 82.1 & 81.1 & 82.2 & 82.7 & 84.1 & 85.6 \\
\hline 2016 & 97.2 & 96.0 & 97.4 & 98.0 & 99.8 & 101.6 \\
\hline \multicolumn{7}{|c|}{ Secondary industry production $\left(10^{9}\right.$ Yuan $)$} \\
\hline 2013 & 628.2 & 633.5 & 631.9 & 638.4 & 628.1 & 628.2 \\
\hline 2014 & 682.5 & 688.6 & 687.4 & 694.0 & 682.4 & 682.5 \\
\hline 2015 & 737.8 & 744.7 & 743.9 & 750.6 & 737.6 & 737.8 \\
\hline 2016 & 794.1 & 801.9 & 801.6 & 808.1 & 793.9 & 794.0 \\
\hline \multicolumn{7}{|c|}{ Third industry production $\left(10^{9}\right.$ Yuan $)$} \\
\hline 2013 & 826.1 & 821.0 & 829.6 & 829.2 & 836.9 & 845.9 \\
\hline 2014 & 966.1 & 959.4 & 970.7 & 970.3 & 980.3 & 991.5 \\
\hline 2015 & 1123.9 & 1115.3 & 1129.9 & 1129.4 & 1142.2 & 1155.5 \\
\hline 2016 & 1299.7 & 1288.9 & 1307.5 & 1306.8 & 1322.7 & 1338.2 \\
\hline
\end{tabular}

(3) Talent incentive coefficient by R\&D: it could reflect how much R\&D resource has been put to motivating the talents.

(4) Port driven coefficient by high technology: it could reflect how much $\mathrm{R} \& \mathrm{D}$ resource has been put to develop new technology and improve the port efficiency.

(5) Logistics driven coefficient by high technology: it could reflect how much $\mathrm{R} \& \mathrm{D}$ resource has been put to develop new technology and improve the added value of logistics industry.

Change the control factors to design six kinds of simulation scheme. The simulation scheme list is shown in Table 2. In Scheme 1 the control factors do not change. In Schemes 2-6 one of the numerical control factors increases $20 \%$.
4.3.2. Results Analysis and Discussion. The variable coefficients are modified according to the above schemes. Then the variation of four economic indexes is studied to confirm the control factors' effect on the port-city system. They include the secondary industry production, third industry production, port throughput, and logistic industry production. The result is showed in Table 3 .

Scheme 1 shows the simulation without coefficients modification. In Scheme 1 the four indexes maintain growing trend. But their growth rates are different. From 2013 to 2016 , the second industry production grows $26.4 \%$, the third industry production grows $57.3 \%$, the port throughput grows $15.9 \%$, and the logistics industry production grows $68.4 \%$. When the system runs under the current economic policy, Shenzhen's secondary and third industry productions would grow significantly. And the latter grows faster than the former. In accordance with the idea of the economic transformation 
from the government, the optimization of the industrial structure is being carried out smoothly.

Comparing the growth rate of the logistics and the overall third industry, the former is more than the latter. It proves that, in the system, the logistics industry is the main driving force of the development of the third industry.

Then calculate "logistics industry production/port throughput" from 2013 to 2016. This ratio represents the logistics output value per cargo unit. The results are 243.15, 276.04, 313.11, and 353.32, keeping increasing. It proves that the trend of economic development is changing from quantitative focus to quality focus.

Schemes 2-6 show the simulations, in which one of the five control factors coefficients is modified. The results are as follows.

In Scheme 2, the fixed-asset investment increases. Compared to Scheme 1, the secondary industry production rises, but the other three indexes remain unchanged or decline slightly. It proves that fixed-asset investment could help develop the secondary industry. But too much facilities construction could not significantly improve the residents' lives and contribute to other industries. This kind of investment driven mode is not a stimulus to the economics at the present stage.

In Scheme 3, the R\&D funding increases. Compared to Scheme 1, all the four indexes are stimulated and keep rising, especially the secondary and the third industry production. The R\&D funding could innovate and optimize the full range of economics. But the port and logistics industry only increase a little. It proves that simply increasing the $R \& D$ input is not enough. Special investment for this industry should be carried out to strengthen its improvement.

In Scheme 4, the R\&D input increases in the aspect of researcher's incentive. Compared to Scheme 1, all the four indexes rise. And, compared to Scheme 3, it increases more. It proves that the $\mathrm{R} \& \mathrm{D}$ funding could not only be one-sided put into the improvement of the research surrounding and materials. The scientific and technical researchers, the main part of R\&D, play a key role in innovation. In order to attract related high-tech talents settled in Shenzhen, the government and the enterprises need to develop effective incentive mechanism, to promote scientific researchers' status in the city from all levels.

In Scheme 5, the R\&D input increases in the aspect of port efficiency improvement. Compared to Scheme 1, the secondary industry production remains unchanged, and the other three indexes rise significantly, especially the port throughput. The R\&D plan of port city should focus on the improvement of the port operation efficiency and provide special funds to strengthen the research of port technology. While the stimulation of fixed-asset investment is weakened gradually, a large number of applications of high technology, such as the internet of things, cloud computing, decision analysis, and optimization system, would realize the port supply chain resources on the seamless connection and coordination. And then improve the port operation efficiency. It will also promote the development of related industries all over the city.
In Scheme 6, the R\&D input increases in the aspect of the logistics industry's added value. Compared to Scheme 1 , the secondary industry production remains unchanged, and the other three indexes rise significantly, especially the third industry and logistics industry productions. Compared to other schemes, their growth is the biggest. It proves that the port city's $R \& D$ plan should focus on not only port operation technology but also the relevant logistics services. In addition to the basic port business, other items can tap the potential value of this industry, including logistics valueadded service development, the logistics personnel training, and information technology for logistics office.

Above all, the decision makers should emphasize putting the limited resources into the different fields. Scheme 1 can be used to maintain the Shenzhen port-city economic system in a good development trend. If adequate resources, Schemes 2 to 6 could be chosen to achieve better growth of different industries.

\section{Conclusion}

The structure of social economic system is complex. This complexity is reflected not only in the structural elements of the system itself, but also in the various elements' connections. This paper establishes a System Dynamics model of the port-city interaction and hopes to analyze and determine the elements' behavioral trends within the system. In different stages of the social development, the growth way of economics is not the same. Study on its developing model must be related to the regional economics, population, key industries, and other aspects. The model simulation proves that the port development relies on the city's economics and relevant industries. In nowadays China, one-sided port facilities investment cannot significantly improve the port business. Special project of R\&D should be carried out to tap the potential value of port and logistics industry. The most important is that when R\&D input has different emphases, the effect is not the same. The direction of $R \& D$ should be adjusted based on the actual situation, to optimize the structure of the secondary and third industries. Finally achieve the economics maintaining steady growth.

\section{Conflict of Interests}

The author declares that there is no conflict of interests regarding the publication of this paper.

\section{Acknowledgment}

This research is supported by the Guangdong Base for Practicing the Scientific View on Development and Social Science Foundation of Lingnan Normal University (YW1404).

\section{References}

[1] Z. Xu, "Theoretical thinking on the port city economic integration," Port Economics, no. 6, pp. 30-31, 2004.

[2] T. E. Notteboom and J.-P. Rodrigue, "Port regionalization: towards a new phase in port development," Maritime Policy \& Management, vol. 32, no. 3, pp. 297-313, 2005. 
[3] G. Sun and Y. Liu, "Revelation of the fourth generation port to China port development," China Ports, no. 6, pp. 16-17, 2005.

[4] C. Ducruet and S.-W. Lee, "Frontline soldiers of globalisation: port-city evolution and regional competition," GeoJournal, vol. 67, no. 2, pp. 107-122, 2006.

[5] I. Grossmann, "Perspectives for Hamburg as a port city in the context of a changing global environment," Geoforum, vol. 39, no. 6, pp. 2062-2072, 2008.

[6] J. Hou, "The sustainable development of port economics based on system dynamics," Systems Engineering-Theory \& Practice, vol. 30, no. 1, pp. 56-61, 2010.

[7] W. Jacobs, C. Ducruet, and P. de Langen, "Integrating world cities into production networks: the case of port cities," Global Networks, vol. 10, no. 1, pp. 92-113, 2010.

[8] K.-Y. Pan and Y.-H. Cao, "The review and prospect of western port geography from 1914 to 2010," Human Geography, no. 6, pp. 32-39, 2014.

[9] J. Zhou, "Speed up the transformation of growth pattern in the new normal stage," China Opening Journal, no. 6, p. 1, 2014.

[10] Z. Chu, "Logistics and economic growth: a panel data approach," The Annals of Regional Science, vol. 49, no. 1, pp. 87102, 2012.

[11] F. M. H. Neffke, M. Henning, and R. Boschma, "The impact of aging and technological relatedness on agglomeration externalities: a survival analysis," Journal of Economic Geography, vol. 12, no. 2, pp. 485-517, 2012.

[12] R. A. Boschma, "The rise of clusters of innovative industries in Belgium during the industrial epoch," Research Policy, vol. 28, no. 8, pp. 853-871, 1999.

[13] R. A. Boschma, "Proximity and innovation. A critical assessment," Regional Studies, vol. 39, no. 1, pp. 61-74, 2005.

[14] K. Frenken and R. A. Boschma, "A theoretical framework for evolutionary economic geography: industrial dynamics and urban growth as a branching process," Journal of Economic Geography, vol. 7, no. 5, pp. 635-649, 2007.

[15] R. Boschma, "Evolutionary economic geography and its implications for regional innovation policy," Papers in Evolutionary Economic Geography, 2009.

[16] F. Neffke, M. Henning, and R. Boschma, "How do regions diversify over time? Industry relatedness and the development of new growth paths in regions," Economic Geography, vol. 87, no. 3, pp. 237-265, 2011.

[17] Y. Meng, "Diversified innovation will become a required course for port development in the new normal stage," China Ports, no. 12, p. 1, 2014.

[18] C. Cao, "Research on the port development in the new normal stage," Port Economics, no. 10, p. 1, 2014.

[19] Y. Ma, Y. Zhao, and Y. Yang, "The interaction of the high-tech industry cluster and the construction of innovative city based on the perspective of system dynamics," Science \& Technology Progress and Policy, vol. 27, no. 9, pp. 50-53, 2010.

[20] M. Fu and J. Lv, "Study on the relationship between port an regional economics based on system dynamics," Journal of Dalian Maritime University, vol. 35, no. 11, pp. 43-46, 2009. 


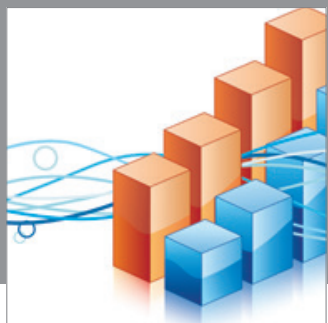

Advances in

Operations Research

mansans

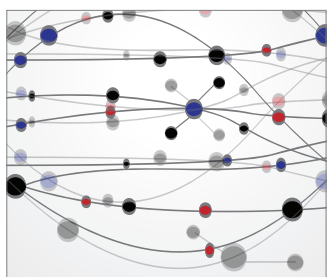

The Scientific World Journal
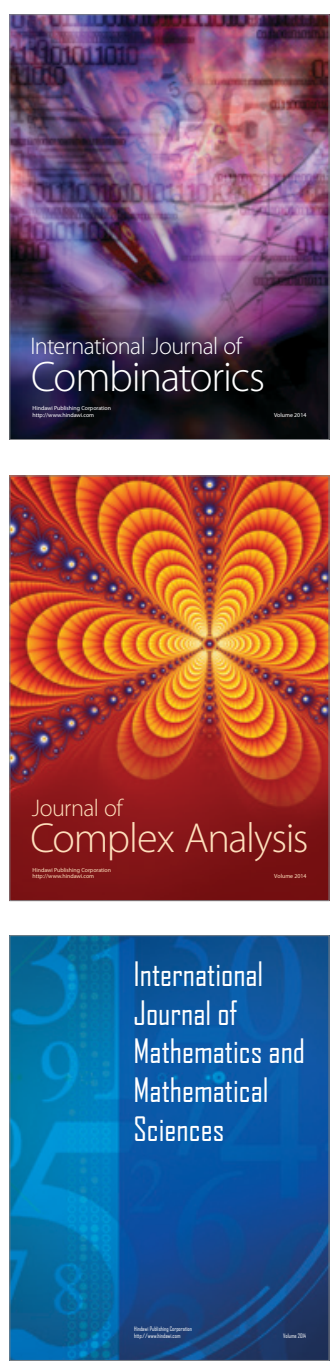
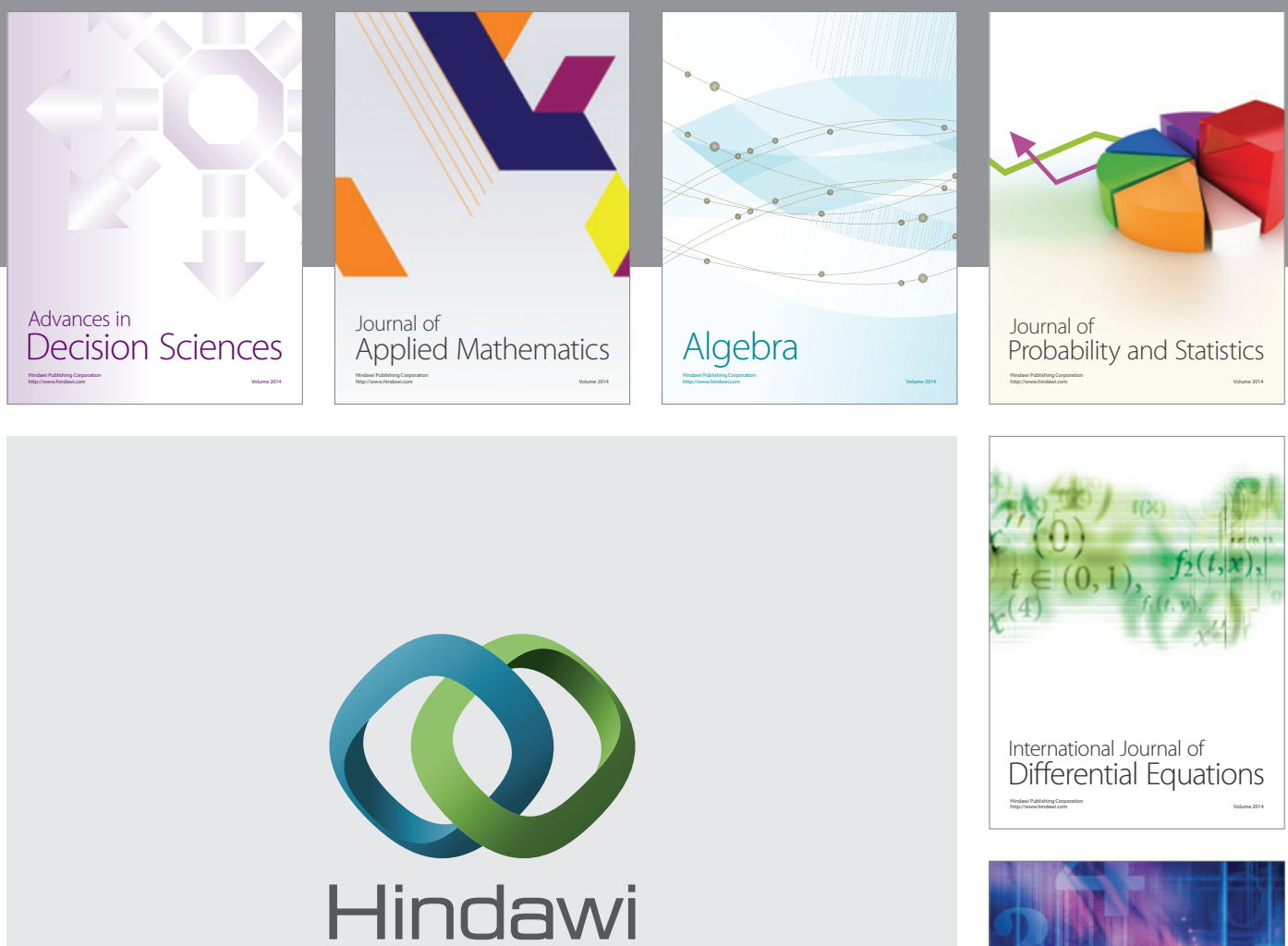

Submit your manuscripts at http://www.hindawi.com
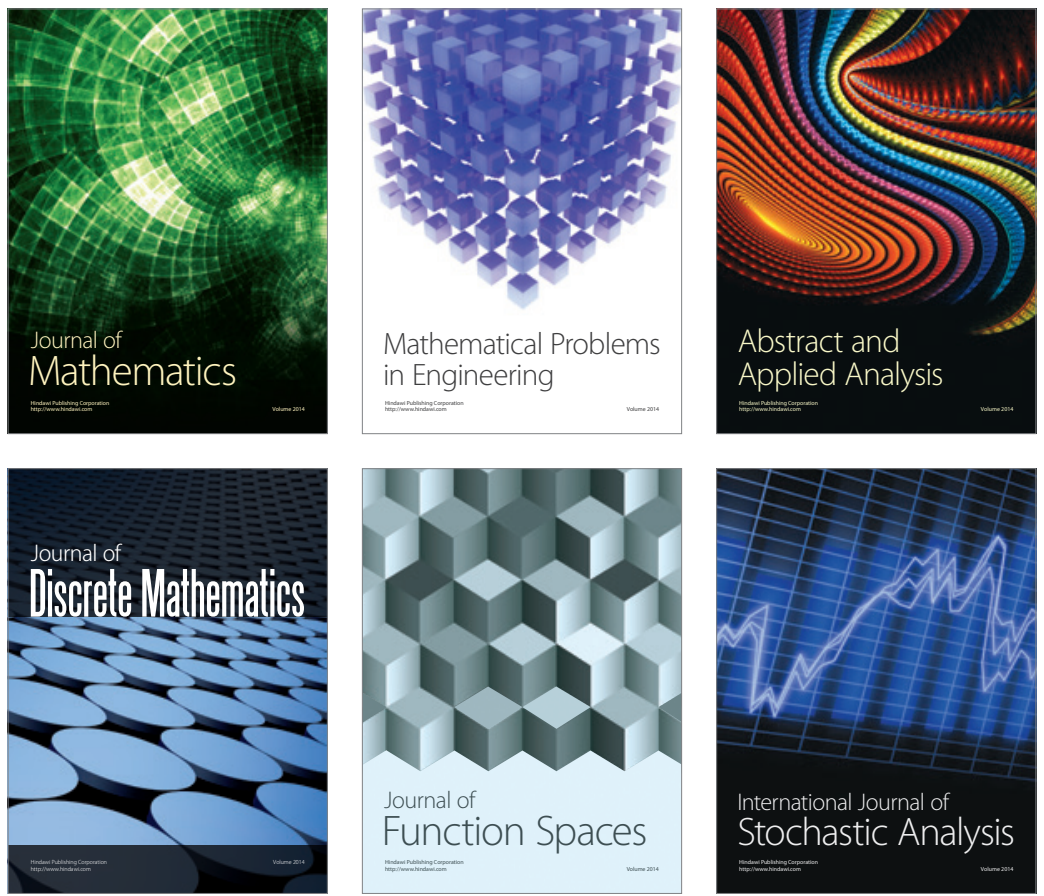

Journal of

Function Spaces

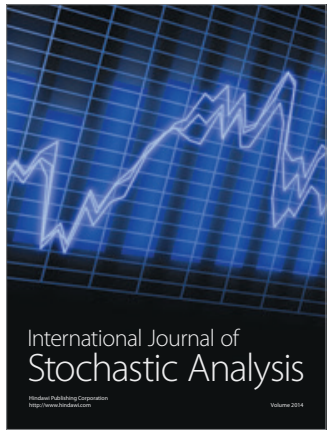

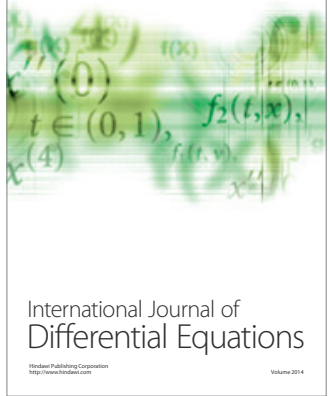
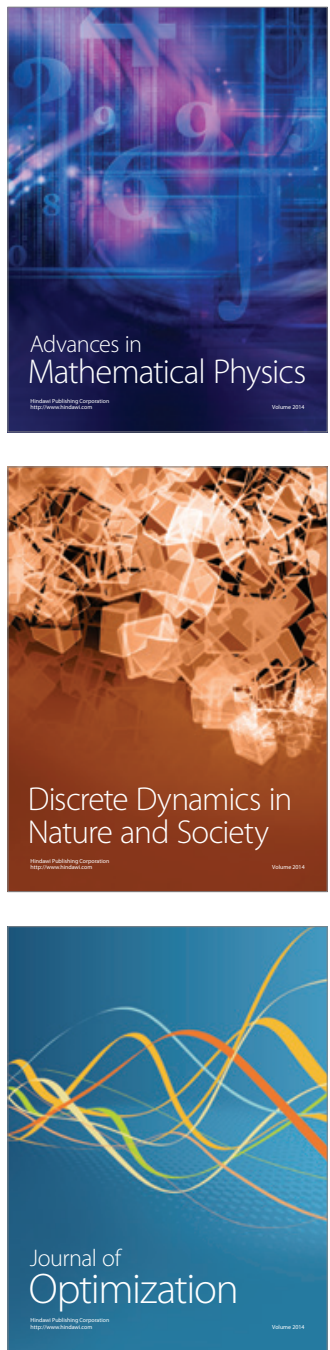